\title{
The Problem of Assessing the Epidemic Risk of Viral Pollution of Water Bodies Using RNA Diagnostics
}

\author{
Nedachin AE*, Dmitrieva RA, Doskina TV, Zagainova AV and Abramov IA \\ Federal State Budgetary Institution, Center for Strategic Planning and Management of Medical and Biological Health Risk. \\ Ministry of Health, Russia
}

*Corresponding author: Nedachin AE, Federal State Budgetary Institution, Center for Strategic Planning and Management of

Medical and Biological Health Risks, Russian Ministry of Health, Russia

\begin{tabular}{|c|c|}
\hline ARTICLE INFO & ABSTRACT \\
\hline Received: 㓞 February 21, 2020 & Citation: Nedachin AE, Dmitrieva RA, Doskina TV, Zagainova AV, Abramov IA. The Problem \\
\hline Published: 蔧 March 03, 2020 & $\begin{array}{l}\text { of Assessing the Epidemic Risk of Viral Pollution of Water Bodies Using RNA Diagnostics. } \\
\text { Biomed J Sci \& Tech Res 26(2)-2020. BJSTR. MS.ID.004318. }\end{array}$ \\
\hline
\end{tabular}

\section{Opinion}

The problem of viral pollution of water bodies of the environment (OOS) is acute in the world. Until recently, sanitary-virological control of water sources and drinking water is carried out directly by direct determination of viruses, as well as using indirect indicators, the most optimal of which are coliphages [1-3]. However, in recent years, researchers have increasingly used viral markers - RNA and DNA of viruses, which are determined in the RT-PCR reaction, both for monitoring viral contamination of water bodies and for deciphering outbreaks of diseases associated with the use of poorquality water or food products that are unfavorable in the epidemic relation. The methodology for the determination of viral markers in the RT-PCR reaction is characterized by high sensitivity, specificity and expressivity, and also makes it possible to quantify them. The introduction of real-time PCR methods can significantly accelerate the determination of genetic markers of viruses in water, which finally will eliminate one of the important drawbacks of traditional cultural sanitary-virological research-a retrospective of the results. If traditional cultural virological analysis requires approximately three weeks, then using real-time PCR, the results can be obtained within a few hours. Optimization of sanitary-virological control of water bodies using the PCR method dictates the need to study the possibilities of its use in various aspects of water supply hygiene, which is extremely important for the rapid adoption of preventive structural and technological decisions.

The results of virologic analysis by PCR are unconditionally used in clinical diagnostics, however, the results of PCR obtained by sanitary-virological monitoring of environmental objects cannot be evaluated unambiguously. Currently, there is no unified approach to the interpretation of the significance of detected viral RNA or DNA, which is extremely necessary when assessing the epidemic danger of the studied object, for example, drinking water after treatment and disinfection. In fact, the detection of virus RNA in water may indicate its contamination with live infectious viruses, which is a real epidemic danger; or viruses inactivated after disinfection, which is not dangerous; or when determining free RNA or DNA isolated from a viral particle at the time of its death and, therefore, also not representing an epidemic danger. The question arises of the need for a test that would test whether the virus whose RNA has been detected is infectious or not. To this end, [4,5] proposed the use of Propidium Monoazide (PMA) in RT-PCR, which was used for differential selective diagnosis of infectious and non-infectious mouse norovirus (MNV-1) after inactivation of its chlorine. However, according to the authors of [4,5], RT-PCR with PMA was not able to differentiate Norvolk infectious viruses from inactivated viruses after any other types of treatment. Thus, RT-PCR with PMA does not allow a distinction to be made between infectious and inactivated viruses after treatment with ultraviolet light, which suggests that damage to the viral capsid may be a prerequisite for the penetration of PMA and binding to the viral genome. Also, according to the authors, this suggests that RT-PCR with PMA can be used to detect intact, potentially infectious viruses MNV-1, Norvolk and to exclude the detection of free viral RNA [6]. 
In addition, viruses and markers of viral contamination can differ in stability and duration of survival under the influence of physical, chemical adverse environmental factors during their circulation, as well as under the influence of disinfecting effects in water treatment conditions, which is extremely important for assessing their indicator significance and the possibility of their use in forecasting the epidemic situation. This dictates the need to study their comparative stability, duration of survival, reliability and priority as indicators of viral contamination in modern water treatment methods. In this regard, studies were carried out, the purpose of which was to study the comparative stability, survival and dynamics of inactivation of the following indicators: coliphages as indirect indicators of viral contamination [7], poliovirus (RV), Hepatitis A Virus (HAV) and their RNA in conditions impact of ultraviolet radiation in drinking water. The obtained data showed that virus RNAs are more resistant to inactivating factors and, in particular, to ultraviolet radiation at the levels of 40 and $60 \mathrm{~mJ} /$ $\mathrm{cm} 2$, and can be longer detected in treated water compared to traditional indicators of viral contamination - phages MS -2, as well as PV viruses detected on BGM tissue culture.

Therefore, if only virus markers are detected in disinfected water - RNA, DNA and the absence of other direct or indirect indicators of viral contamination, it is impossible to unambiguously judge the degree of potential epidemic hazard of a water body. This requires the development of reliable additional tests confirming the infectivity of viruses detected by RNA or DNA markers, and in particular, the improvement and refinement of tests using propidium monoazide [8,9], as well as the analysis of additional factors confirming the potential epidemic danger: the presence of specific sanitary -hygienic conditions, including the entry of viral contamination, the presence in the water of indirect indicators of viral contamination-coliphages [10] or directly detection of infectious viruses in water.

ISSN: 2574-1241

DOI: 10.26717/BJSTR.2020.26.004318

Nedachin AE. Biomed J Sci \& Tech Res

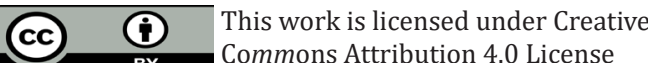

Submission Link: https://biomedres.us/submit-manuscript.php

\section{References}

1. Nedachin AE, Dmitrieva RA, Doskina TV, Dolgin VA (2015) Indicative value of individual indicators and markers for viral water contamination. Hygiene and sanitation 6: 51-54.

2. Nedachin AE, Dmitrieva RA, Doskina TV, Dolgin VA (2014) Indicators and markers of viral water pollution. Materials of the Plenum of the Scientific Council of the Russian Federation on Human Ecology and Environmental Hygiene "Integrated Impact of Environmental Factors and Lifestyles on Public Health: Diagnostics, Correction, Prevention.” pp. 276-278.

3. Income $\mathrm{N}$, Kosoltanapiwat $\mathrm{N}$, Taksinoros $\mathrm{S}$, Leaungwutiwong P, Maneekan P, et al. (2019) Molecular Identification of Enteroviruses from Cattle and Goat Feces and Environment in Thailand. Appl Environ Microbiol 85(5): pii: e02420-18.

4. Nedachin AE, Dmitrieva RA, Doskina TV (2015) The effect of chemical pollution on the ratio of indicator microorganisms and intestinal viruses in the water of surface water bodies. Materials of the Plenum of the Scientific Council of the Russian Federation on Human Ecology and Environmental Hygiene, M., 17-18 pp. 297-300.

5. Marinho ANR, Rocha DCC, Kanai YK, Alves CM, Costa DC, et al. (2018) Rotavirus analyses by SYBR Green real-time PCR and microbiological contamination in bivalves cultivated in coastal water of Amazonian Brazil. J Water Health 16(6): 970-979.

6. Lowther JA, Henshilwood K, Lees DN (2008) Determination of norovirus contamination in oysters from two commercial harvesting areas over an extended period, using semiquantitative real-time reverse transcription PCR. J Food Prot 71(7): 1427-1433.

7. Karim MR, Fout GS, Johnson CH, White KM, Parshionikar SU (2015) Propidium monoazide reverse transcriptase PCR and RT-qPCR for detecting infectious enterovirus and norovirus. J Virol Methods 219: 51-61.

8. Parshionikar S, Laseke I, Fout GS (2010) Use of Propidium Monoazide in Reverse Transcriptase PCR To Distinguish between Infectious and Noninfectious Enteric Viruses in Water Samples. Appl Environ Microbiol 76(13): 4318-4326.

9. Farkas K, Varsani A, Marjoshi D, Easingwood R, McGill E, et al. (2014) Size exclusion-based purification and PCR-based quantitation of MS2 bacteriophage particles for environmental applications. J Virol Methods 213: $135-138$

10. Kitajima M, Tohya Y, Matsubara K, Haramoto E, Utagawa E, et al. (2010) Chlorine inactivation of human norovirus, murine norovirus and poliovirus in drinking water. Lett Appl Microbiol 51(1): 119-121.

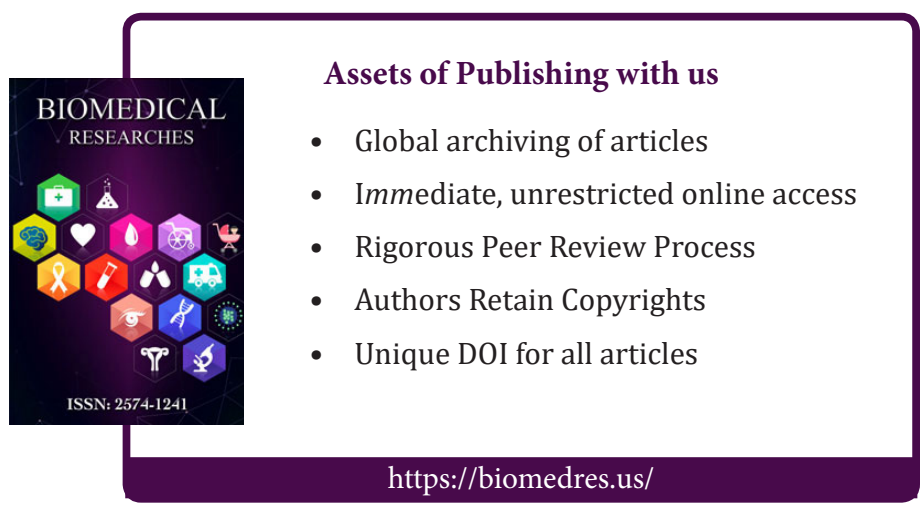

Copyright@ Nedachin AE | Biomed J Sci \& Tech Res | BJSTR. MS.ID.004318. 